University of Nebraska - Lincoln

DigitalCommons@University of Nebraska - Lincoln

Faculty Papers and Publications in Animal

Science

Animal Science Department

February 1990

\title{
ABSORPTION OF EQUATIONS FOR NON-PARENTS FOR AN ANIMAL MODEL WITH MATERNAL EFFECTS AND GENETIC GROUPS
}

L. Dale Van Vleck

University of Nebraska-Lincoln, dvan-vleck1@unl.edu

Follow this and additional works at: https://digitalcommons.unl.edu/animalscifacpub

Part of the Animal Sciences Commons

Van Vleck, L. Dale, "ABSORPTION OF EQUATIONS FOR NON-PARENTS FOR AN ANIMAL MODEL WITH MATERNAL EFFECTS AND GENETIC GROUPS" (1990). Faculty Papers and Publications in Animal Science. 347.

https://digitalcommons.unl.edu/animalscifacpub/347

This Article is brought to you for free and open access by the Animal Science Department at DigitalCommons@University of Nebraska - Lincoln. It has been accepted for inclusion in Faculty Papers and Publications in Animal Science by an authorized administrator of DigitalCommons@University of Nebraska - Lincoln. 


\title{
ABSORPTION OF EQUATIONS FOR NON-PARENTS FOR AN ANIMAL MODEL WITH MATERNAL EFFECTS AND GENETIC GROUPS 1
}

\author{
L. D. Van Vleck² \\ U.S. Department of Agriculture, Lincoln, NE 68583-0908
}

\begin{abstract}
Rules for forming the mixed-model equations for the reduced animal model with all relationships and including maternal effects have been set out by Quaas and Pollak. They also have shown how to simplify the mixed-model equations when genetic group effects are included in the model with what has become known as the Q-P transformation. Westell has given rules for calculating the coefficients for the Q-P transformed equations that are associated with the inverse of the numerator relationship matrix and genetic group effects. Those rules can be extended to include maternal effects and genetic groups for maternal as well as direct effects. As with the rules of Quaas and Pollak for the equations for the reduced animal model, a similar set of rules can be obtained for the genetic groups model after the Q-P transformation. The rules are derived easily by examining the algebraic results of absorbing the direct and maternal breeding value equations for non-parents into the parent breeding value, group and fixed effects equations. These rules involve Westell's rules and the inverse elements of the genetic (co)variance matrix for direct and maternal additive genetic effects. The rules make calculation of breeding values for parents for models including direct and maternal genetic group effects nearly as easy as for models without genetic group effects. Back solution for direct and maternal breeding values of non-parents similarly is as simple as when genetic group effects are not in the model.
\end{abstract}

(Key Words: Genetic Analysis, Transformation, Breeding Value, Genetic Models.)

J. Anim. Sci. 1990. 68:4014-4025

Introduction

Quaas and Pollak (1980) introduced the reduced animal model (RAM) for genetic evaluation using as a basic model the so-called animal model. The RAM is based on a model containing additive genetic value of the animal with the record. Essentially, RAM results from forming an equivalent model (Henderson, 1985) that gives mixed-model equations (MME) that are equivalent to those after absorbing equations for additive genetic values of nonparent animals. The computational advantages often are substantial, with many fewer equations and, more significantly, many fewer solutions and right-hand-sides, which are most efficiently kept in computer memory. Most genetic evaluation programs for beef cattle use RAM (Benyshek et al., 1988) rather than iterating on data, which is based usually on the full set of equations (Schaeffer and Kennedy, 1986a,b; Wiggans et al., 1988a,b).

Quaas and Pollak (1981) showed how to transform the MME when genetic group effects are in the model to calculate breeding values (genetic group effect plus deviation from mean group effect) rather than deviation of additive values from genetic group effect and genetic group effects separately. These equations will be denoted as the Q-P equations. This

'Published as Paper No. 9006 Journal Ser., Nebraska Agric. Res. Div., Univ. of Nebraska, Lincoln 68583-0908.

${ }^{2}$ ARS, Roman L. Hruska, U.S. Meat Anim. Res. Center, A218 Anim. Sci., Univ. of Nebraska, Lincoln 685830908 .

Received August 25, 1989.

Accepted February 9, 1990. 
transtormation reduces the number of coefficients in the MME and generally increases rate of convergence if the equations are solved by iteration (Van Vleck and Dwyer, 1985).

Westell (1984) discovered some simple rules for calculating the coefficients of the Q-P transformed equations. She augmented the MME to include base animals without records (Henderson, 1977), applied an appropriate Q-P transformation, absorbed the breeding value equations for the base animals, and then observed that the coefficients due to numerator relationships and group effects followed a simple pattern. The result is Westell's rules (Westell, 1984; Westell et al., 1984, 1988; Quaas, 1988). The resulting equations will be called the Q-P$\mathrm{W}$ equations. The assignment of groups by Westell (1984) is similar to a development by Thompson (1979) and is the same as proposed by Robinson (1986). Westell's rules are as simple as Henderson's (1976) rules for calculating the inverse of the numerator relationship matrix. Group effects and numerator relationships are incorporated into genetic evaluations of dairy cattle that use the additive genetic animal model using Westell's rules (Wiggans et al., 1988a,b; Robinson and Chesnais, 1988).

Van Vleck (1990) extended the use of Westell's rules to a model including maternal effects with separate genetic group effects for both direct and maternal effects by including a final female ancestor without records in the solution vector for direct effects and by assigning both of her parents to the genetic group she would have been assigned for a model without maternal effects. Currently neither direct nor maternal genetic group effects are considered with an animal model for genetic evaluations of beef cattle performed routinely in the U.S. (L. L. Benyshek and J. S. Brinks, personal communications, 1989).

The purpose of this note is to show that by absorbing the non-parent equations of the Q-PW equations that include direct and maternal group effects, coefficients for equations comparable to RAM equations without genetic group effects can be calculated easily.

\section{Results}

\section{Mixed-Model Equations for Model with Direct and Maternal Genetic Effects}

The mixed model considered by Van Vleck (1990) for animals with a vector of single records, $\mathrm{y}$, is $\mathrm{y} \square \mathrm{X} \boldsymbol{\beta}+\mathrm{Za}_{1}+\mathrm{ZA}_{10} \mathrm{Q}_{0} \mathrm{~g}_{\mathrm{a}}+\mathrm{Sm}_{1}+\mathrm{SA}_{10} \mathrm{Q}_{0} \mathrm{~g}_{\mathrm{m}}+\mathrm{Sp}+\mathrm{e}$, where $\mathrm{X}$ associates fixed effects in $\beta$ with $y, Z$ associates additive genetic effects in $a_{1}$ with $y, Z A_{10} Q_{0}$ associates additive direct group effects in $g_{a}$ with $y, S$ associates maternal genetic effects in $m_{1}$ and nongenetic maternal effects in $\mathrm{p}$ with $\mathrm{y}, \mathrm{SA}_{10} \mathrm{Q}_{0}$ associates maternal group effects in $\mathbf{g}_{\mathrm{m}}$ with $\mathrm{y}$, and $\mathrm{e}$ is a vector of independent residuals.

The fractional contribution of genetic group effects to breeding values is $\mathrm{A}_{10} \mathrm{Q}_{0} \mathrm{~g}_{\mathrm{a}}$ for additive direct genetic effects and $A_{10} Q_{0} g_{m}$ for maternal genetic effects with $Q_{0}$ a matrix that assigns base animals to groups (Thompson, 1979; Westell, 1984; Westell et al., 1984, 1988; Robinson, 1986; Quaas, 1988; Wiggans et al., 1988a), where $A_{10}$ is the matrix of the numerator relationships between animals in $\mathrm{a}_{1}\left(\right.$ or $\left.\mathrm{m}_{1}\right)$ and base animals. Non-base animals without records are included in $\mathrm{a}_{1}$ or $\mathrm{m}_{\mathrm{l}}$ by including corresponding zero columns in $\mathrm{Z}$ and $\mathrm{S}$ (see Henderson, 1977).

$$
\mathrm{E}\left(\begin{array}{c}
\mathrm{y} \\
\mathrm{a}_{1} \\
\mathrm{~m}_{\mathrm{l}} \\
\mathrm{p} \\
\mathrm{e}
\end{array}\right)=\left(\begin{array}{c}
\mathrm{X} \beta+\mathrm{ZA}_{10} \mathrm{Q}_{0} \mathrm{~g}_{\mathrm{a}}+\mathrm{SA}_{10} \mathrm{Q}_{0} \mathrm{~g}_{\mathrm{m}} \\
0 \\
0 \\
0 \\
0
\end{array}\right)
$$

For the same animals in $\mathrm{a}_{1}$ and $\mathrm{m}_{1}$

$$
\mathrm{V}\left(\begin{array}{c}
\mathrm{a}_{1} \\
\mathrm{~m}_{1} \\
\mathrm{p} \\
\mathrm{e}
\end{array}\right)=\left(\begin{array}{cccc}
\mathrm{A}_{11} \sigma_{\mathrm{a}}^{2} & \mathrm{~A}_{11} \sigma_{\mathrm{am}} & 0 & 0 \\
\mathrm{~A}_{11} \sigma_{\mathrm{am}} & \mathrm{A}_{11} \sigma_{\mathrm{m}}^{2} & 0 & 0 \\
0 & 0 & \mathrm{I} \sigma_{\mathrm{p}}^{2} & \\
0 & 0 & 0 & \mathrm{I} \sigma_{\mathrm{e}}^{2}
\end{array}\right)
$$


where $A_{11}$ is the numerator relationship matrix among animals in $a_{1}$ (and $m_{1}$ ), $\sigma_{a}^{2}, \sigma_{a}^{2}, \sigma_{\mathrm{p}}^{2}, \sigma_{\mathrm{e}}^{2}$, are variances for additive direct, additive maternal, nongenetic and nonadditive genetic maternal, and environmental effects and $\sigma_{\mathrm{am}}$ is the covariance between additive direct and additive maternal effects.

$$
\begin{aligned}
& \text { Let }\left(\begin{array}{ll}
\alpha & \lambda \\
\lambda & \gamma
\end{array}\right)=\sigma_{\mathrm{e}}^{2}\left(\begin{array}{cc}
\sigma_{\mathrm{a}}^{2} & \sigma_{\mathrm{am}} \\
\sigma_{\mathrm{am}} & \sigma_{\mathrm{m}}^{2}
\end{array}\right)^{-1} \text { and } \delta=\sigma_{\mathrm{e}}^{2} / \sigma_{\mathrm{p}}^{2} \\
& \text { Let } \mathrm{W}=\left(\begin{array}{ll}
\mathrm{W}_{11} & \mathrm{~W}_{12} \\
\mathrm{~W}_{12}^{\prime} & \mathrm{W}_{22}
\end{array}\right) \text { be the }
\end{aligned}
$$

coefficients due to numerator relationships and group effects as calculated by Westell's rules where the subscript 1 corresponds to breeding value equations and the subscript 2 corresponds to group equations. Also, let $\mathrm{Q} \square \mathrm{A}_{10} \mathrm{Q}_{0}$ to simplify writing equations.

The resulting MME, the Q-P-W equations, (after multiplying left-hand and right-hand sides by $\sigma_{\mathrm{e}}^{2}$ ) are:

$$
\left(\begin{array}{cccccc}
\mathrm{X}^{\prime} \mathrm{X} & \mathrm{X}^{\prime} \mathrm{S} & \mathrm{X}^{\prime} \mathrm{Z} & 0 & \mathrm{X}^{\prime} \mathrm{S} & 0 \\
\mathrm{~S}^{\prime} \mathrm{X} & \mathrm{S}^{\prime} \mathrm{S}+\mathrm{I} \delta & \mathrm{S}^{\prime} \mathrm{Z} & 0 & \mathrm{~S}^{\prime} \mathrm{S} & 0 \\
\mathrm{Z}^{\prime} \mathrm{X} & \mathrm{Z}^{\prime} \mathrm{S} & \mathrm{Z}^{\prime} \mathrm{Z}+\alpha \mathrm{W}_{11} & \alpha \mathrm{W}_{12} & \mathrm{Z}^{\prime} \mathrm{S}+\lambda \mathrm{W}_{11} & \lambda \mathrm{W}_{12} \\
0 & 0 & \alpha \mathrm{W}_{12}^{\prime} & \alpha \mathrm{W}_{22} & \lambda \mathrm{W}_{12}^{\prime} & \lambda \mathrm{W}_{22} \\
\mathrm{~S}^{\prime} \mathrm{X} & \mathrm{S}^{\prime} \mathrm{S} & \mathrm{S}^{\prime} \mathrm{Z}+\lambda \mathrm{W}_{11} & \lambda \mathrm{W}_{12} & \mathrm{~S}^{\prime} \mathrm{S}+\gamma \mathrm{W}_{11} & \gamma \mathrm{W}_{12} \\
0 & 0 & \lambda \mathrm{W}_{12}^{\prime} & \lambda \mathrm{W}_{22} & \gamma \mathrm{W}_{12}^{\prime} & \gamma \mathrm{W}_{22}
\end{array}\right)\left(\begin{array}{c}
\hat{\beta} \\
\hat{\mathrm{p}} \\
\hat{\mathrm{a}}_{1}+\mathrm{Q} \hat{\mathrm{g}}_{\mathrm{a}} \\
\hat{\mathrm{g}}_{\mathrm{a}} \\
\hat{\mathrm{m}}_{1}+\mathrm{Q} \hat{\mathrm{g}}_{\mathrm{m}} \\
\hat{\mathrm{g}}_{\mathrm{m}}
\end{array}\right)=\left(\begin{array}{c}
\mathrm{X}^{\prime} \mathrm{y} \\
\mathrm{S}^{\prime} \mathrm{y} \\
\mathrm{Z}^{\prime} \mathrm{y} \\
0 \\
\mathrm{~S}^{\prime} \mathrm{y} \\
0
\end{array}\right)
$$

The $\mathrm{p}$ equations for animals included in $\mathrm{m}$ that are not mothers will have zero coefficients and right-hand sides so that effective number of $p$ equations is the number of mothers with progeny having records rather than the number of elements in $\mathrm{m}$. A non-zero equation in $\mathrm{p}$, however, will be associated with each pair of non-parent equations, for which absorption will be described in the next section.

In the Q-P-W form, all the parts of $\mathrm{W}$ with the same multiplier $(\alpha, \lambda$ or $\gamma)$ are blocked together. The direct breeding value and direct group effects computationally are a subvector of solutions, as are maternal breeding values and maternal group effects.

\section{Absorption of Non-Parent Equations}

Let

$$
\hat{\mathrm{a}}^{*}=\left(\begin{array}{c}
\hat{\mathrm{a}}_{1}+\mathrm{Q} \hat{\mathrm{g}}_{\mathrm{a}} \\
\hat{\mathrm{g}}_{\mathrm{a}}
\end{array}\right) \text { and } \hat{\mathrm{m}}^{*}=\left(\begin{array}{c}
\hat{\mathrm{m}}_{\mathrm{l}}+\mathrm{Q} \hat{\mathrm{g}}_{\mathrm{m}} \\
\hat{\mathrm{g}}_{\mathrm{m}}
\end{array}\right)
$$

where the top parts of the vectors correspond to breeding values for direct and maternal effects.

To obtain the computing advantages comparable to those with RAM, the equations for direct, $\hat{a}^{*}$, and maternal, $\hat{m}^{*}$, breeding values of non-parents can be absorbed easily. A set of rules will be developed for calculating elements of the coefficient matrix and right-hand-side vector. Terms that will arise in the absorption of the non-parent equations (those will be contained in the top parts of $\hat{a}^{*}$ and $\hat{\mathrm{m}}^{*}$ ) will be defined here. The absorption will occur as a block for each non-parent corresponding to the animal's additive direct and additive maternal equations. The notation for the inverse of the diagonal block for a non-parent is: 


$$
\left(\begin{array}{ll}
\alpha^{*} & \lambda^{*} \\
\lambda^{*} & \gamma^{*}
\end{array}\right)=\left(\begin{array}{cc}
1+\mathrm{D} \alpha & \mathrm{D} \lambda \\
\mathrm{D} \lambda & \mathrm{D} \gamma
\end{array}\right)^{\prime}=\mathrm{DEN}\left(\begin{array}{cc}
\mathrm{D} \gamma & -\mathrm{D} \lambda \\
-\mathrm{D} \lambda & 1+\mathrm{D} \alpha
\end{array}\right)
$$

where $\mathrm{DEN}=1 /[\mathrm{D}(\gamma+\mathrm{aD} \gamma-\lambda \mathrm{D} \lambda)]$

and according to the rules of Westell:

$\mathrm{D}=2$, if both parents are in $\mathrm{a}_{1}$ and the animal is not inbred (if inbred, then adjust as described by Quaas [1976, 1988].

$\mathrm{D}=4 / 3$, if one parent is in $\mathrm{a}_{1}$ and other parent is proxied by a group and

$\mathrm{D}=1$, if neither parent is in $\mathrm{a}_{1}$ and both parents are proxied by groups.

Terms which arise in the absorption will be assigned briefer symbols as follows:

$$
\begin{aligned}
& \phi_{0}=1-\alpha^{*} \\
& \phi_{1}=\mathrm{D}\left(\alpha \alpha^{*}+\lambda \lambda^{*}\right) / 2=\left(1-\alpha^{*}\right) / 2=\phi_{0} / 2 \\
& \phi_{2}=\mathrm{D}\left(\lambda \alpha^{*}+\gamma \lambda^{*}\right) / 2=0 \\
& \phi_{3}=\mathrm{D}^{2}\left(\alpha \alpha \alpha^{*}+2 \alpha \lambda \lambda^{*}+\lambda \lambda \gamma^{*}\right) / 4=\left(\mathrm{D} \alpha+\alpha^{*}-1\right) / 4 \\
& \phi_{4}=\mathrm{D}^{2}\left(\alpha \lambda \alpha^{*}+\lambda \lambda \lambda^{*}+\alpha \gamma \lambda^{*}+\lambda \gamma \gamma^{*}\right) / 4 \\
& =\mathrm{D} \lambda / 4
\end{aligned}
$$

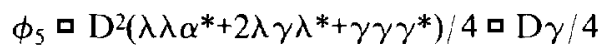

Note that some of these terms simplify considerable, especially with $\phi_{2}$ ㅁ 0 . A reviewer pointed out these simplifications of $\phi_{1}$ and $\phi_{3}$ which further simplify the rules for absorbing equations of non-parents. These terms will change with each non-parent, depending on what $\mathrm{D}$ is. Advantage can be taken in computing in the non-inbred case that only three different values of $\phi_{0}$ are possible. Only for an inbred animal, which can occur only if both parents are not proxied, will $\phi_{0}$ not be predetermined.

Examination of the coefficients each non-parent record generates for the Westell form of the Q-P transformed equations leads directly to how to absorb the two equations for each non-parent. Some of the elements come from the least squares portion of MME and some from calculation of $W$.

\begin{tabular}{|c|c|c|c|c|c|c|c|c|c|}
\hline \multirow{2}{*}{$\begin{array}{l}\text { Equation } \\
\text { (row) }\end{array}$} & \multicolumn{8}{|c|}{ Column } & \multirow{2}{*}{$\begin{array}{l}\text { Right-hand } \\
\text { side }\end{array}$} \\
\hline & $\mathrm{a}_{\mathrm{i}}^{*}$ & $\mathrm{~m}_{\mathrm{i}}^{*}$ & $\beta_{\mathrm{k}}$ & $\mathrm{p}_{\mathrm{j}}$ & $a_{5}^{*}$ & $\mathrm{~m}_{\mathrm{s}}^{*}$ & $\mathrm{a}_{\mathrm{j}}^{*}$ & $m_{j}^{*}$ & \\
\hline$a_{j}^{*}$ & $1+D \alpha$ & $\mathrm{D} \lambda$ & 1 & I & $\mathrm{D} \alpha / 2$ & $\mathrm{DN} / 2$ & $\mathrm{D} \alpha: 2$ & $1 \mathrm{D} \lambda / 2$ & $y_{i}$ \\
\hline $\mathrm{m}_{\mathrm{i}}^{*}$ & $\mathrm{D} \lambda$ & $\mathrm{D} \gamma$ & 0 & 0 & $-\mathrm{D} \lambda: 2$ & $\ldots$ D $\gamma: 2$ & $\ldots \mathrm{D} \lambda / 2$ & $\cdots \mathrm{D} \gamma / 2$ & 0 \\
\hline$\beta_{k}$ & 1 & 0 & 1 & 1 & 0 & 0 & 0 & 1 & $y_{i}$ \\
\hline $\mathrm{p}_{\mathrm{j}}$ & 1 & 0 & 1 & 1 & 0 & 0 & 0 & 1 & $y_{i}$ \\
\hline$a_{s}^{*}$ & $\mathrm{D} \alpha 2$ & $-\mathrm{D} \lambda: 2$ & 0 & 0 & $\mathrm{D} \alpha \mathbf{4}$ & $\mathrm{D} \lambda: 4$ & $\mathrm{D} \alpha / 4$ & $D \lambda 4$ & 0 \\
\hline $\mathrm{m}_{3}^{*}$ & $-\mathrm{D} \lambda / 2$ & $\mathrm{D} \gamma: 2$ & 0 & 0 & $\mathrm{D} \lambda_{i} 4$ & $\mathrm{D} \gamma: 4$ & $\mathrm{D} \lambda / 4$ & D $\gamma / 4$ & 0 \\
\hline$a_{i}^{*}$ & $-\mathrm{D} \alpha / 2$ & $-\mathrm{D} \lambda ; 2$ & 0 & 0 & $\mathrm{D} \alpha ; 4$ & $\mathrm{D} \lambda \lambda_{4}$ & $\mathrm{D} \alpha / 4$ & $\mathrm{D} \lambda: 4$ & 0 \\
\hline$m^{*}$ & $1-\mathrm{D} \lambda: 2$ & $-\mathrm{D} \gamma: 2$ & 1 & 1 & $\mathrm{D} \lambda: 4$ & $\mathrm{D} \gamma: 4$ & $D \lambda: 4$ & $1+D \gamma 4$ & $y_{i}$ \\
\hline
\end{tabular}

For illustration, assume only fixed effect $\beta_{k}$ is associated with record $y_{i}$ of non-parent $i$ that has father, $s$, and mother, $\mathrm{j}$. If the father is assigned to a group, then $s$ identifies the group of the father. Thus, the coefficients associated with non-parent, $i$, with record $y_{i}$ are in Table 1 .

TABLE 1. CONTRIBUTIONS TO COEFFICIENT MATRIX AND RIGHT-HAND-SIDE VECTOR ASSOCIATED WITH A NON-PARENT, i, THAT HAS FATHER (OR PROXY), s. AND MOTHER, j, AND THAT HAS RECORD, $y_{i}$, CONTAINING FIXED EFFECT, $\beta_{k}$ 
TABLE 2. ELEMENTS, AFTER SIMPLIFICATION, CONTRIBUTED TO COEFFICIENT MATRIX AND RIGHT-HAND-SIDE VECTOR RESULTING FROM ABSORPTION OF EQUATIONS FOR NON-PARENT, $i$, THAT HAS FATHER (OR PROXY), s, AND MOTHER, j, AND THAT HAS RECORD, $y_{i}$, CONTAINING FIXED EFFECT, $\beta_{k}$

\begin{tabular}{|c|c|c|c|c|c|c|c|}
\hline \multirow{2}{*}{$\begin{array}{l}\text { Equation } \\
\text { (row) }\end{array}$} & \multicolumn{6}{|c|}{ Column } & \multirow{2}{*}{$\begin{array}{l}\text { Right-hand } \\
\text { side }\end{array}$} \\
\hline & $\beta_{\mathrm{k}}$ & $\mathrm{p}_{\mathrm{j}}$ & $a_{\mathrm{s}}^{*}$ & $\mathrm{~m}_{\mathrm{s}}^{*}$ & $a_{j}^{*}$ & $\mathrm{~m}_{\mathrm{j}}^{*}$ & \\
\hline$\beta_{\mathrm{k}}$ & \multirow[t]{3}{*}{$\phi_{0}$} & $\phi_{0}$ & $\phi_{0} / 2$ & 0 & $\phi_{0} / 2$ & $\phi_{0}$ & $\phi_{0} y_{i}$ \\
\hline $\mathrm{p}_{\mathrm{j}}$ & & $\phi_{0}$ & $\phi_{0} / 2$ & 0 & $\phi_{0} / 2$ & $\phi_{0}$ & $\phi_{0} y_{i}$ \\
\hline$a_{s}^{*}$ & & & $\phi_{0} / 4$ & 0 & $\phi_{0} / 4$ & $\phi_{0} / 2$ & $.5 \phi_{0} y_{i}$ \\
\hline $\mathrm{m}_{5}^{*}$ & \multirow{3}{*}{\multicolumn{2}{|c|}{ Symmetric }} & & 0 & 0 & 0 & 0 \\
\hline$a_{j}^{*}$ & & & & & $\phi_{0} / 4$ & $\phi_{0} / 2$ & $.5 \phi_{0} \mathrm{y}_{\mathrm{i}}$ \\
\hline $\mathrm{m}_{\mathrm{j}}^{*}$ & & & & & & $\phi_{0}$ & $\phi_{0} \mathrm{y}_{\mathrm{i}}$ \\
\hline
\end{tabular}

Note that the mother of a non-parent is included in $a_{1}$ and $m_{1}$ (Van Vleck, 1990) and,thus, $j$ will not identify a group. Further reflection and examination will reveal that no other records or relatives will contribute to the two equations for the non-parent, those for $\hat{a}_{i}^{*}$ and $\hat{\mathrm{m}}_{\mathrm{i}}^{*}$. Thus, the two equations for $\hat{\mathrm{a}}_{\mathrm{i}}^{*}$ and $\hat{\mathrm{m}}_{\mathrm{i}}^{*}$ can be block-absorbed into the other cells shown in Table 1. The results of that absorption are in terms of $\phi$ 's, $\alpha, \lambda, \gamma, \mathrm{D}$ and $\mathrm{y}_{\mathrm{i}}$.

Further examination reveals that some of these elements can be simplified. As mentioned earlier, the following equalities can be shown relatively easily by substituting for $\alpha^{*}, \lambda^{*}$ and $\gamma^{*}$ terms in $\mathrm{D}, \alpha, \lambda$ and $\gamma$. Thus, $\phi_{2}$ 口 $0, \mathrm{D} \lambda / 4-\phi_{4}=0, \mathrm{D} \gamma / 4-\phi_{5}=0$. Table 2 shows the results of these identities and provides rules for computing elements to add to the cells of the coefficient matrix and right-hand sides for each non-parent.

Absorption results in new non-zero entries (fill) in four cells of the coefficient matrix: fixed effect by direct breeding values of father and mother and non-genetic maternal effect by direct breeding values of father and mother, but not for cells associated with maternal breeding value of sire. Only three kinds of coefficients are needed, although all depend on the value of $\mathrm{D}: \phi_{0}=1-\alpha^{*} ; \phi_{1}=\left(1-\alpha^{*}\right) / 2=\phi_{0} / 2$ and $\mathrm{D} \alpha / 4-\phi_{3}=\phi_{0} / 4$. For each non-parent, a set of three coefficients needs to be calculated $\left(\phi_{0}, \phi_{0} / 2\right.$ and $\left.\phi_{0} / 4\right)$ or taken from the set of three coefficients precalculated, corresponding to the D associated with the non-parent. Table 2 is a set of rules for processing a non-parent record to form the coefficient matrix, corresponding to a reduced animal model with direct and maternal genetic groups.

For completeness, Table 3 provides the rules for processing contributions to the absorbed equations for parents that have records. Some parents may not be base animals and may not have records. Rules for processing contributions of parents without records are in Table 4. The only difference between rules in Table 3 and in Table 4 is that animals without records do not contribute l's to the cells associated with the least squares parts of the MME.

TABLE 3. ELEMENTS OF COEFFICIENT MATRIX AND RIGHT-HAND-SIDE VECTOR CONTRIBUTED BY A RECORD $y_{i}$ OF A PARENT, $i$; WITH SIRE (OR PROXY GROUP), s: WITH DAM (OR PROXY GROUP, j. IF THE DAM IS A PROXY GROUP, THEN NOTHING IS ADDED TO RIGHT-HAND-SIDE FOR $p_{i}$ OR TO ROWS AND COLUMNS ASSOCIATED WITH $p_{i}$

\begin{tabular}{|c|c|c|c|c|c|c|c|c|c|}
\hline \multirow{2}{*}{$\begin{array}{l}\text { Equation } \\
\text { (row) }\end{array}$} & \multicolumn{8}{|c|}{ Column } & \multirow{2}{*}{$\begin{array}{l}\text { Right-hand } \\
\text { side }\end{array}$} \\
\hline & $\beta_{\mathrm{k}}$ & $\mathrm{p}_{\mathrm{j}}$ & $\mathrm{a}_{\mathrm{i}}^{*}$ & $\mathrm{~m}_{\mathrm{i}}^{*}$ & $a_{\mathrm{s}}^{*}$ & $\mathrm{~m}_{\mathrm{s}}^{*}$ & $a_{j}^{*}$ & $\mathrm{~m}_{\mathrm{j}}^{*}$ & \\
\hline$\beta_{\mathrm{k}}$ & 1 & 1 & 1 & & & & & 1 & $y_{i}$ \\
\hline $\mathrm{p}_{j}$ & 1 & 1 & 1 & & & & & 1 & $y_{i}$ \\
\hline$a_{i}^{*}$ & 1 & 1 & $1+\mathrm{D} \alpha$ & $\mathrm{D} \lambda$ & $-\mathrm{D} \alpha / 2$ & $\mathrm{D} \lambda / 2$ & $-D \alpha / 2$ & $1-\mathrm{D} \lambda / 2$ & $y_{i}$ \\
\hline$m_{i}^{*}$ & & & $\mathrm{D} \lambda$ & $\mathrm{D} \gamma$ & $\mathrm{D} \lambda / 2$ & $-\mathrm{D} \gamma / 2$ & $\mathrm{D} \lambda / 2$ & $-D \gamma / 2$ & 0 \\
\hline$a_{s}^{*}$ & & & $-\mathrm{D} \alpha_{2} 2$ & $\mathrm{D} \lambda / 2$ & $\mathrm{D} \alpha / 4$ & $\mathrm{DN} / 4$ & $D \alpha / 4$ & $\mathrm{D} \lambda / 4$ & 0 \\
\hline $\mathrm{m}_{\mathrm{s}}^{*}$ & & & $-\mathrm{D} \lambda / 2$ & $-\mathrm{D} \gamma / 2$ & $\mathrm{D} \lambda / 4$ & $\mathrm{D} \gamma / 4$ & $\mathrm{D} \lambda / 4$ & $\mathrm{D} \gamma / 4$ & 0 \\
\hline$a_{j}^{*}$ & & & $-\mathrm{D} \alpha / 2$ & $-\mathrm{D} \lambda / 2$ & $\mathrm{D} \alpha / 4$ & $\mathrm{DN} / 4$ & $\mathrm{D} \alpha / 4$ & $\mathrm{D} \lambda / 4$ & 0 \\
\hline$m_{j}^{*}$ & 1 & 1 & $1-D \lambda / 2$ & $-\mathrm{D} \gamma / 2$ & $\mathrm{D} \lambda / 4$ & $\mathrm{D} \gamma / 4$ & $D \lambda / 4$ & $1+D_{\gamma} / 4$ & $y_{i}$ \\
\hline
\end{tabular}


TABLE 4. ELEMENTS OF COEFFICIENT MATRIX CONTRIBUTED BY A PARENT WITHOUT A RECORD, i; WITH SIRE (OR PROXY), s; WITH DAM (OR PROXY GROUP), j

\begin{tabular}{|c|c|c|c|c|c|c|c|}
\hline \multirow{2}{*}{$\begin{array}{l}\text { Equation } \\
\text { (row) }\end{array}$} & \multicolumn{6}{|c|}{ Column } & \multirow{2}{*}{$\begin{array}{l}\text { Right-hand } \\
\text { side }\end{array}$} \\
\hline & $a_{i}^{*}$ & $\mathrm{~m}_{\mathrm{i}}^{*}$ & $a_{s}^{*}$ & $\mathrm{~m}_{\mathrm{s}}^{*}$ & $a_{j}^{*}$ & $\mathrm{~m}_{\mathrm{j}}^{*}$ & \\
\hline$a_{i}^{*}$ & $\mathrm{D} \alpha$ & D $\lambda$ & $-\mathrm{D} \alpha / 2$ & $-D \lambda: 2$ & $-\mathrm{D} \alpha: 2$ & $-\mathrm{D} \lambda / 2$ & 0 \\
\hline $\mathrm{m}_{\mathrm{i}}^{*}$ & $\mathrm{D} \lambda$ & D $\gamma$ & $-\mathrm{D} \lambda / 2$ & $-\mathrm{D} \gamma 2$ & $-D \lambda 2$ & $-\mathrm{D} \gamma: 2$ & 0 \\
\hline$a_{s}^{*}$ & $-\mathrm{D} \alpha / 2$ & $-\mathrm{D} \lambda / 2$ & $\mathrm{D} \alpha_{i} 4$ & $\mathrm{D} \lambda: 4$ & $\mathrm{D} \alpha \mathbf{4}$ & $\mathrm{D} \lambda / 4$ & 0 \\
\hline $\mathrm{m}_{\mathrm{s}}^{*}$ & $-\mathrm{D} \lambda / 2$ & $-\mathrm{D} \gamma / 2$ & $\mathrm{D} \lambda, 4$ & $D \gamma 4$ & $\mathrm{D} \lambda 4$ & Dr: 4 & 0 \\
\hline$a_{j}^{*}$ & $-\mathrm{D} \alpha / 2$ & $-\mathrm{D} \lambda / 2$ & $\mathrm{D} \alpha \mathbf{4}$ & $\mathrm{D} \lambda: 4$ & $\mathrm{D} \alpha 4$ & $\mathrm{D} \lambda 4$ & 0 \\
\hline $\mathrm{m}_{\mathrm{j}}^{*}$ & $-\mathrm{D} \lambda / 2$ & $-\mathrm{D} \gamma / 2$ & $\mathrm{D} \lambda / 4$ & $\mathrm{D} \gamma: 4$ & $\mathrm{D} \lambda: 4$ & Dy 4 & 0 \\
\hline
\end{tabular}

Tables 2, 3 and 4 provide the rules for setting up the equivalent of the RAM equations. The final step is to add the ratio, $\delta=\sigma_{\mathrm{e}}^{2} / \sigma_{\mathrm{p}}^{2}$, to the diagonal coefficients of the equations for the nongenetic maternal effects.

The net result of the Q-P transformation, as pointed out by Quaas and Pollak (1980), is fewer equations and thus fewer total coefficients, although the remaining coefficient matrix will be slightly more dense. With one fixed factor (e.g., contemporary groups), after absorption non-zero coefficients result for the following four cells: fixed effect, direct breeding value of sire; fixed effect, direct breeding value of dam; nongenetic maternal effect of dam, direct breeding value of sire; and nongenetic maternal effect of dam, direct breeding value of dam. Absorption leads to contributions to right-hand sides for direct breeding values of sire and dam. If the sire and dam have records, then no new non-zero right-hand sides are generated by absorption of non-parent equations. Absorption of the direct and maternal breeding value equations for non-parents eliminates those two equations, including 13 nonzero (half-stored) coefficients and one non-zero right-hand side. The absorption also results in zero contributions to the $\left(\mathrm{a}_{\mathrm{s}}^{*}, \mathrm{~m}_{\mathrm{s}}^{*}\right),\left(\mathrm{m}_{\mathrm{s}}^{*}, \mathrm{~m}_{\mathrm{s}}^{*}\right),\left(\mathrm{m}_{\mathrm{s}}^{*}, \mathrm{a}_{\mathrm{j}}^{*}\right)$, and $\left(\mathrm{m}_{\mathrm{s}}^{*}, \mathrm{~m}_{\mathrm{j}}^{*}\right)$ cells, whereas non-zero coefficients are generated for those cells by a non-parent record. The $\left(a_{s}^{*}, m_{s}^{*}\right)$ and $\left(m_{s}^{*}, m_{s}^{*}\right)$ cells will likely fill anyway, but the other two probably will not. The net result of the absorption of each non-parent with one fixed factor is likely to be a reduction of two equations and solutions and 11 non-zero coefficients.

The effect on computing efficiency will depend on many factors, including memory capacity relative to number of equations. The blocks of coefficients corresponding to genetic groups may be quite dense. If non-parents are not absorbed, the right-hand sides for genetic groups are zero. Westell (1984) has described some computing strategies for a simpler model with the Q-P-W equations. Group solutions seemed to converge more slowly than other classes of solutions. Block iteration is an option because the block size is such that a one-time inversion is not costly. The group equations would be solved last so that the right-hand sides would be adjusted for other effects in those equations.

\section{Backsolutions for Non-Parents}

After solutions are obtained for parents, groups and fixed effects, the coefficients of the equations for a non-parent shown in the first two rows of Table 1 can be used to calculate the predicted breeding values for direct and maternal genetic effects. The coefficients to do the initial absorption and the solutions for other effects in the equations are needed. Thus, with the vector of solutions for the equations after absorption, the file of non-parents can be read to calculate solutions for breeding values.

For a particular D associated with animal i, calculate as for absorption

$$
\left(\begin{array}{ll}
\alpha^{*} & \lambda^{*} \\
\lambda^{*} & \gamma^{*}
\end{array}\right)=\left(\begin{array}{cc}
1+\mathrm{D} \alpha & \mathrm{D} \lambda \\
\mathrm{D} \lambda & \mathrm{D} \gamma
\end{array}\right)^{\prime}
$$


Then for, $s$, the sire or proxy group for the sire and, $j$, the dam and, $k$, the indicator of the fixed effect level:

$$
\left(\begin{array}{c}
\hat{a}_{i}^{*} \\
\hat{m}_{i}^{*}
\end{array}\right)=\left(\begin{array}{cc}
\alpha^{*} & \lambda^{*} \\
\lambda^{*} & \gamma^{*}
\end{array}\right)\left(\begin{array}{c}
y_{i}-\hat{\beta}_{\mathrm{k}}-\hat{\mathrm{p}}_{\mathrm{j}}-\hat{\mathrm{m}}_{\mathrm{j}}^{*}+\mathrm{D} \alpha\left(\hat{\mathrm{a}}_{\mathrm{s}}^{*+} \hat{\mathrm{a}}_{\mathrm{j}}^{*}\right) / 2+\mathrm{D} \lambda\left(\hat{\mathrm{m}}_{\mathrm{s}}^{*}+\hat{\mathrm{m}}_{\mathrm{j}}^{*}\right) / 2 \\
\mathrm{D} \lambda\left(\hat{\mathrm{a}}_{\mathrm{s}}^{*}+\hat{\mathrm{a}}_{\mathrm{j}}^{*}\right) / 2+\mathrm{D} \gamma\left(\hat{\mathrm{m}}_{\mathrm{s}}^{*+}+\hat{\mathrm{m}}_{\mathrm{j}}^{*}\right) / 2
\end{array}\right) .
$$

\section{Multiple Traits}

Obviously, extension of these rules to multiple traits can follow the same steps as was shown by Quaas and Pollak (1980). The terms will become more complex and will involve the environmental variances and covariances among the traits. If records are available for some traits and not for other traits for a non-parent, the inverse of the associated environmental variance-covariance matrix will involve only the traits with records. As in the Quaas and Pollak (1980) development, records of some traits may include maternal effects and others may not. The potential number of combinations of traits, missing records and maternal effects is such that no effort will be made here to develop a general set of rules. An obvious approach to a particular combination of traits and maternal effects is to set up symbolically the Westell equations for a non-parent and follow through the absorption, as was done here, or to develop rules from an equivalent model as done by Quaas and Pollak (1980) for the animal model without genetic group effects.

\section{Example}

The example is based on Figure 1 . Animals $C_{1}, C_{2}$ and $C_{3}$ are non-parents. Animal $S$ does not have a record but has two collateral descendants. Animals $P_{1}$ and $P_{2}$ do not have records but are included because they contribute maternal effects to records of animals $B$ and $C_{1}$. Genetic groups have been assigned as proxy parents for nearest ancestors without records. Proxy parents of $P_{1}$ (also $P_{2}$ ) are assigned to the genetic group that $P_{1}$ (also $P_{2}$ ) would have been assigned for a model without maternal effects as suggested by Van Vleck (1990). Assume $\sigma_{\mathrm{a}}^{2}=4, \sigma_{\mathrm{am}}=.5, \sigma_{\mathrm{m}}^{2}=1, \sigma_{\mathrm{p}}^{2} \square 2$ and $\sigma_{\mathrm{e}}^{2} \square 10$. Then $\alpha \square 2 . \overline{6}, \lambda=1 . \overline{3} \gamma=10 . \overline{6}$ and $\delta$ a 5.0, where.$\overline{\mathrm{F}}$ indicates a repeating fraction, .FFFF...F.

The direct and maternal solutions for an animal often are paired for computational convenience. Thus, for this example, the vector of solutions is:

$\left(\hat{\mu} \hat{p}_{\mathrm{B}} \hat{\mathrm{p}}_{\mathrm{P}_{1}} \hat{\mathrm{p}}_{\mathrm{P}_{2}} \hat{\mathrm{a}}_{\mathrm{B}}^{*} \hat{\mathrm{m}}_{\mathrm{B}}^{*} \hat{\mathrm{a}}_{\mathrm{P}_{1}}^{*} \hat{\mathrm{m}}_{\mathrm{P}_{1}}^{*} \hat{\mathrm{a}}_{\mathrm{P}_{2}}^{*} \hat{\mathrm{m}}_{\mathrm{P}_{2}}^{*} \mathrm{a}_{\mathrm{S}}^{*} \hat{\mathrm{m}}_{\mathrm{S}}^{*} \hat{\mathrm{g}}_{\mathrm{a} 1} \hat{\mathrm{g}}_{\mathrm{m} 1} \hat{\mathrm{g}}_{\mathrm{a} 2} \hat{\mathrm{g}}_{\mathrm{m} 2} \hat{\mathrm{a}}_{\mathrm{C}_{1}}^{*} \hat{\mathrm{m}}_{\mathrm{C}_{\mathrm{i}}}^{*} \hat{\mathrm{a}}_{\mathrm{C}_{2}}^{*} \hat{\mathrm{m}}_{\mathrm{C}_{2}}^{*} \hat{\mathrm{a}}_{\mathrm{C}_{3}}^{*} \hat{\mathrm{m}}_{\mathrm{C}_{3}}^{*}\right)^{\prime}$.

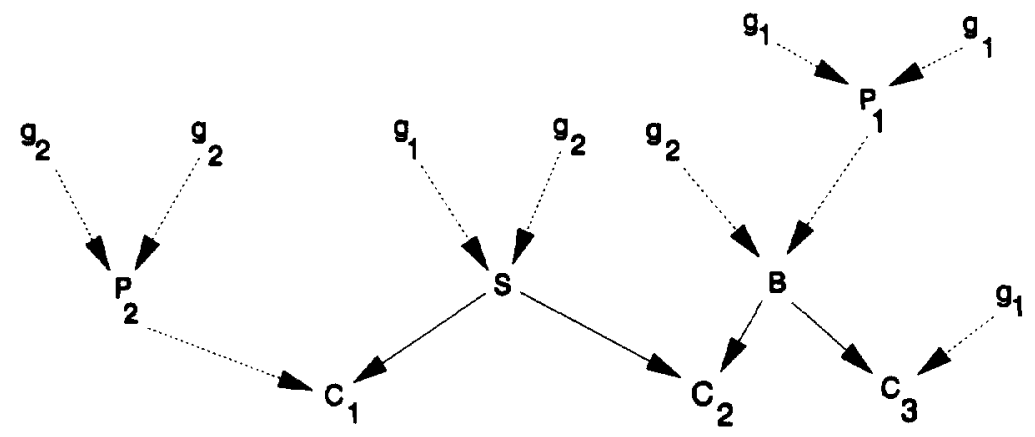

Figure 1. Diagram for example. Animals $B, C_{1}, C_{2}$ and $C_{3}$ have records of 130, 100, 110 and 120. Animals $P_{1}, P_{2}$, and $B$ contribute maternal effects to records of $B, C_{1}, C_{2}$ and $C_{3}$. Genetic groups $\left(g_{1}\right.$ or $\left.g_{2}\right)$ are assigned as shown: parents of most recent female ancestor without records are assigned to the group that female ancestor would have been assigned if no maternal effects influence the trait. 
For calculation of $\mathrm{W}$, and of $\alpha^{*}, \lambda^{*}, \gamma^{*}$, the values of $\mathrm{D}$ are 2 for $\mathrm{C}_{1}$ and $\mathrm{C}_{2}, 4 / 3$ for $\mathrm{C}_{3}$ and $\mathrm{B}$, and 1 for $S, P_{1}$, and $P_{2}$. Then for $W$ calculated in order of $B, P_{1}, P_{2}, S, g_{1}, g_{2}, C_{1}, C_{2}, C_{3}$ :

$\mathrm{W}=\left(\begin{array}{ccccccccc}2.17 & -.67 & 0 & .50 & .33 & -.67 & 0 & -1 & -.67 \\ & 1.33 & 0 & 0 & -1.0 & .33 & 0 & 0 & 0 \\ & & 1.50 & .50 & 0 & -1 & -1 & 0 & 0 \\ & & & 2 & -.5 & -.5 & -1 & -1 & 0 \\ \text { Symmetric } & & & 1.58 & .25 & 0 & 0 & -.67 \\ & & & & & 1.58 & 0 & 0 & 0 \\ & & & & & 2 & 0 & 0 \\ & & & & & & & & 0 \\ & & & & & & & & 1.33\end{array}\right)$

The full set of coefficients for equations including non-parents in order of the solution vector is:

\begin{tabular}{|c|c|c|c|c|c|c|c|c|c|c|c|c|c|c|c|c|c|c|c|c|}
\hline \multirow[t]{8}{*}{2.0} & 1.0 & 1.0 & 1.0 & 2.0 & 0 & 1.0 & 0 & 1.0 & 0 & 0 & 0 & 0 & 0 & 0 & 1.0 & 0 & 1.0 & 0 & 1.0 & 0 \\
\hline & 0 & 0 & 0 & 2.0 & 0 & 0 & 0 & 0 & 0 & 0 & 0 & 0 & 0 & 0 & 0 & 0 & 1.0 & 0 & 1.0 & 0 \\
\hline & 6.0 & 0 & 1.0 & 0 & 0 & 1.0 & 0 & 0 & 0 & 0 & 0 & 0 & 0 & 0 & 0 & 0 & 0 & 0 & 0 & 0 \\
\hline & & 6.0 & 0 & 0 & 0 & 0 & 0 & 1.0 & 0 & 0 & 0 & 0 & 0 & 0 & 1.0 & 0 & 0 & 0 & 0 & 0 \\
\hline & & & 6.7 & -2.8 & -1.7 & 1.8 & 0 & 0 & 1.3 & -.6 & .8 & -.4 & 1.7 & .8 & 0 & 0 & -2.6 & 1.3 & -1.7 & .8 \\
\hline & & & & 25.1 & .8 & -7.1 & 0 & 0 & -.6 & 5.3 & .4 & 3.5 & .8 & 7.1 & 0 & 0 & 2.3 & -10.6 & 1.8 & -7.1 \\
\hline & & & & & 3.5 & -1.7 & 0 & 0 & 0 & 0 & -2.6 & 1.3 & .8 & -.4 & 0 & 0 & 0 & 0 & 0 & 0 \\
\hline & & & & & & 15.2 & 0 & 0 & 0 & 0 & 1.3 & -10.6 & 4 & 3.5 & 0 & 0 & 0 & 0 & 0 & 0 \\
\hline Sy & $\mathrm{nm}$ & trio & & & & & 4.0 & 2.0 & 1.3 & -6 & 0 & 0 & -2.6 & 1.3 & -2.6 & 1.3 & 0 & 0 & 0 & 0 \\
\hline \multirow{13}{*}{ All d } & & & & & & & & 17.0 & .6 & 5.3 & 0 & 0 & 1.3 & -10.6 & 2.3 & -10.6 & 0 & 0 & 0 & 0 \\
\hline & peat & ing & & & & & & & 5.3 & -2.6 & -1.3 & .6 & -1.3 & 6 & -2.6 & 1.3 & .2 .6 & 1.3 & 0 & 0 \\
\hline & & & & & & & & & & 21.3 & .6 & -5.3 & .6 & -5.3 & 1.3 & 10.6 & 1.3 & -10.6 & 0 & 0 \\
\hline & & & & & & & & & & & 4.2 & -2.1 & .6 & -.3 & 0 & 0 & 0 & 0 & -1.7 & .8 \\
\hline & & & & & & & & & & & & 16.8 & -.3 & 2.6 & 0 & 0 & 0 & 0 & .8 & -7.1 \\
\hline & & & & & & & & & & & & & 4.2 & -2.1 & 0 & 0 & 0 & 0 & 0 & 0 \\
\hline & & & & & & & & & & & & & & 16.8 & 0 & 0 & 0 & 0 & 0 & 0 \\
\hline & & & & & & & & & & & & & & & 6.3 & 26 & 0 & 0 & 0 & 0 \\
\hline & & & & & & & & & & & & & & & & 21.3 & 0 & 0 & 0 & 0 \\
\hline & & & & & & & & & & & & & & & & & 6.3 & -2.6 & 0 & 0 \\
\hline & & & & & & & & & & & & & & & & & & 21.3 & 0 & 0 \\
\hline & & & & & & & & & & & & & & & & & & & 4.5 & -1.7 \\
\hline & & & & & & & & & & & & & & & & & & & & 14.2 \\
\hline
\end{tabular}

The right-hand-side vector is shown in the left column of Table 5.

Two Lagrange multiplier equations were used to obtain an inverse of the coefficient matrix and a direct set of solutions to the equations. These solutions are shown in the second column of Table 5. The constraint equations were $\hat{\mathrm{g}}_{\mathrm{a} 1}+\hat{\mathrm{g}}_{\mathrm{a} 2}=0$ and $\hat{\mathrm{g}}_{\mathrm{m} 1}+\hat{\mathrm{g}}_{\mathrm{m} 2}=0$.

The rules shown in Tables 2,3 and 4 were used to set up the reduced equations for the same example.

For parent with record, $\mathrm{B}$, with sire in group 2 and dam, $\mathrm{P}_{1}$; the $\mathrm{D}$ value is $4 / 3$ so that $\alpha^{*}=$ $.231, \lambda^{*}=.029, \gamma^{*}=.074$, and $\phi_{0}=.769$. Contributions to right-hand sides: 130 to $\mu, \mathrm{p}_{\mathrm{P}_{1}}, \hat{a}_{\mathrm{B}}^{*}$, $\hat{m}_{\mathrm{P}}^{*}$.

Contributions to the coefficient matrix are (without repeating the symmetrical off-diagonal terms):

1 to $\left(\mu\right.$ with $\left.\mu, \mathrm{p}_{\mathrm{P}_{1}}, \mathrm{a}_{\mathrm{B}}^{*}, \mathrm{~m}_{\mathrm{P}_{1}}^{*}\right)$, with $\left(\mathrm{p}_{\mathrm{P}_{1}}\right.$ with $\left.\mathrm{p}_{\mathrm{p}_{1}}, \mathrm{a}_{\mathrm{B}}^{*}, \mathrm{~m}_{\mathrm{P}_{1}}^{*}\right)$

$$
\begin{aligned}
& 4.556 \text { to }\left(\mathrm{a}_{\mathrm{B}}^{*}, \mathrm{a}_{\mathrm{B}}^{*}\right) \\
& -1.778 \text { to }\left(\mathrm{a}_{\mathrm{B}}^{*} \text { with } \mathrm{m}_{\mathrm{B}}^{*}, \mathrm{a}_{\mathrm{P}_{\mathrm{i}}}^{*}, \mathrm{~g}_{\mathrm{a} 2}\right) \\
& 1.889 \text { to }\left(\mathrm{a}_{\mathrm{B}}^{*}, \mathrm{~m}_{\mathrm{P}_{1}}^{*}\right)
\end{aligned}
$$


TABLE 5. RIGHT-HAND-SIDE VECTORS AND SOLUTION VECTORS FOR EXAMPLE FOR FULL SET OF EQUATIONS AND AFTER USE OF RULES TO OBTAIN EQUATIONS AFTER ABSORPTION OF EQUATIONS FOR NON-PARENTS.a

\begin{tabular}{|c|c|c|c|c|}
\hline \multirow[b]{2}{*}{ Symbolic solution } & \multicolumn{2}{|c|}{ Before absorption } & \multicolumn{2}{|c|}{ Absorbed equations } \\
\hline & Right-hand sides & Solutions & Right-hand sides & Solutions \\
\hline$\mu$ & 460 & 115.33 & 397.3 & 115.33 \\
\hline $\mathrm{p}, \mathrm{B}$ & 230 & -.49 & 184.0 & -.49 \\
\hline $\mathrm{p}, \mathrm{P}_{1}$ & 130 & .24 & 130.0 & .24 \\
\hline $\mathrm{p}, \mathrm{P}_{2}$ & 100 & .24 & 83.3 & .24 \\
\hline$A^{*}, B$ & 130 & -.09 & 222.0 & -.09 \\
\hline $\mathrm{m}^{*}, \mathrm{~B}$ & 230 & -.18 & 184.0 & -.18 \\
\hline$A^{*}, P_{1}$ & 0 & 7.60 & 0 & 7.60 \\
\hline $\mathrm{m}^{*}, \mathrm{p}_{\mathrm{l}}$ & 130 & 13.30 & 130.0 & 13.30 \\
\hline$a^{*}, P_{2}$ & 0 & -7.29 & 41.7 & -7.29 \\
\hline $\mathrm{m}^{*}, \mathrm{P}_{2}$ & 100 & -13.15 & 83.3 & -13.15 \\
\hline$a^{*}, S$ & 0 & -.49 & 87.5 & -.49 \\
\hline$m *, S$ & 0 & -.06 & 0 & -.06 \\
\hline $\mathrm{g}_{1}, \mathrm{a}$ & 0 & 7.60 & 46.2 & 7.60 \\
\hline $\mathrm{g}_{1}, \mathrm{~m}$ & 0 & 13.30 & 0 & 13.30 \\
\hline $\mathbf{g}_{2}, \mathbf{a}$ & 0 & -7.60 & 0 & -7.60 \\
\hline $\mathrm{g}_{2}, \mathrm{~m}$ & 0 & -13.30 & 0 & -13.30 \\
\hline $\mathrm{a}^{*}, \mathrm{C}_{1}$ & 100 & -3.65 & & \\
\hline $\mathrm{m}^{*}, \mathrm{C}_{1}$ & 0 & -6.57 & & \\
\hline$a^{*}, C_{2}$ & 110 & -1.02 & & \\
\hline $\mathrm{m}^{*}, \mathrm{C}_{2}$ & 0 & -.21 & & \\
\hline$a^{*}, C_{3}$ & 120 & 4.12 & & \\
\hline $\mathrm{m}^{*}, \mathrm{C}_{3}$ & 0 & 6.60 & & \\
\hline Lagrange & 0 & .00 & 0 & 0 \\
\hline multipliers & 0 & .00 & 0 & 0 \\
\hline
\end{tabular}

${ }^{a} \mathrm{p}, \mathrm{k}$ is permanent maternal environmental effect for animal $\mathrm{k} . \mathrm{a}^{*}, \mathrm{k}$ is direct breeding value, $\mathrm{a}^{+} \mathrm{Qg}, \mathrm{a}$, for animal $\mathrm{k}, \mathrm{m}^{*}, \mathrm{k}$ is maternal breeding value, $\mathrm{m}+\mathrm{Qg}_{\mathrm{m}}$, for animal $\mathrm{k}$. $\mathrm{g}_{\mathrm{i}}$ are group effects, direct $=\mathrm{a}$ and maternal $=\mathrm{m}$.

.889 to $\left(a_{B}^{*}, g_{m 2}\right),\left(m_{B}^{*}\right.$ with $\left.a_{P_{1}}^{*}, g_{a 2}\right),\left(a_{P_{1}}^{*}\right.$, with $\left.a_{P_{1}}^{*}, g_{a 2}\right),\left(g_{a 2}, g_{a 2}\right)$

$$
\begin{aligned}
& 14.222 \text { to }\left(\mathrm{m}_{\mathrm{B}}^{*}, \mathrm{~m}_{\mathrm{B}}^{*}\right) \\
& -7.111 \text { to }\left(\mathrm{m}_{\mathrm{B}}^{*} \text { with } \mathrm{m}_{\mathrm{P}_{1}}^{*}, \mathrm{~g}_{\mathrm{m} 2}\right) \\
& -.444 \text { to }\left(\mathrm{a}_{\mathrm{P}_{1}}^{*} \text { with } \mathrm{m}_{\mathrm{P}_{1}}^{*}, \mathrm{~g}_{\mathrm{m} 2}\right),\left(\mathrm{m}_{\mathrm{P}_{1}}^{*}, \mathrm{~g}_{\mathrm{a} 2}\right),\left(\mathrm{g}_{\mathrm{a} 2}, \mathrm{~g}_{\mathrm{m} 2}\right) \\
& 4.556 \text { to }\left(\mathrm{m}_{\mathrm{P}_{1}}^{*}, \mathrm{~m}_{\mathrm{P}_{1}}^{*}\right) \\
& 3.556 \text { to }\left(\mathrm{m}_{\mathrm{P}_{1}}^{*}, \mathrm{~g}_{\mathrm{m} 2}\right),\left(\mathrm{g}_{\mathrm{m} 2}, \mathrm{~g}_{\mathrm{m} 2}\right) .
\end{aligned}
$$

For parent without record, $\mathrm{P}_{1}$, with sire and dam both in group 1; the $\mathrm{D}$ value is 1 so that $\alpha^{*}$ $=.286, \lambda^{*}=.036, \gamma^{*}=.098$, and $\phi_{0}=.714$. Contributions to right-hand sides: none.

Contributions to coefficient matrix:

$$
\begin{aligned}
& 2.667 \text { to }\left(\mathrm{a}_{\mathrm{P}_{1}}^{*}, \mathrm{a}_{\mathrm{P}_{1}}^{*}\right),\left(\mathrm{g}_{\mathrm{a}}, \mathrm{g}_{\mathrm{a}}\right) \\
& -1.333 \text { to }\left(\mathrm{a}_{\mathrm{P}_{1}}^{*}, \mathrm{~m}_{\mathrm{P}_{1}}^{*}\right),\left(\mathrm{g}_{\mathrm{a} 1}, \mathrm{~g}_{\mathrm{m} 1}\right) \\
& -2.667 \text { to }\left(\mathrm{a}_{\mathrm{P}_{1}}^{*}, \mathrm{~g}_{\mathrm{a} 1}\right) \\
& 1.333 \text { to }\left(\mathrm{a}_{\mathrm{P}_{1}}^{*}, \mathrm{~g}_{\mathrm{m} 1}\right),\left(\mathrm{m}_{\mathrm{P}_{1}}^{*}, \mathrm{~g}_{\mathrm{a}}\right) \\
& 10.667 \text { to }\left(\mathrm{m}_{\mathrm{P}_{1}}^{*}, \mathrm{~m}_{\mathrm{P}_{1}}^{*}\right),\left(\mathrm{g}_{\mathrm{m} 1}, \mathrm{~g}_{\mathrm{m} 1}\right) \\
& -10.667 \text { to }\left(\mathrm{m}_{\mathrm{P}_{1}}^{*}, \mathrm{~g}_{\mathrm{m} 1}\right) .
\end{aligned}
$$


Contributions for $P_{2}$ are identical to those of $P_{1}$ with $P_{2}$ substituted for $P_{1}$ and $a_{2}$ and $m_{2}$ substituted for $\mathrm{a}_{1}$ and $\mathrm{m}_{1}$.

For parent without records, $\mathrm{S}$, with sire in group 1 and dam in group 2; the D value is 1.0 so that $\alpha^{*}=.286, \lambda^{*}=.036, \gamma^{*}=.098$, and $\phi_{0}=.714$. Contributions to right-hand sides: none.

Contributions to coefficient matrix:

$$
\begin{aligned}
& 2.667 \text { to }\left(a_{\mathrm{S}}^{*}, a_{\mathrm{S}}^{*}\right),\left(\mathrm{g}_{\mathrm{m} 1} \text { with } \mathrm{g}_{\mathrm{m}_{1}}, \mathrm{~g}_{\mathrm{m}_{2}}\right),\left(\mathrm{g}_{\mathrm{m}_{2}}, \mathrm{~g}_{\mathrm{m}_{2}}\right) \\
& -1.333 \text { to }\left(\mathrm{a}_{\mathrm{S}}^{*} \text { with } \mathrm{m}_{\mathrm{S}}^{*}, \mathrm{~g}_{\mathrm{a}_{1}}, \mathrm{~g}_{\mathrm{a}_{2}}\right) \\
& \quad .667 \text { to }\left(\mathrm{a}_{\mathrm{S}}^{*} \text { with } \mathrm{g}_{\mathrm{m}_{1}}, \mathrm{~g}_{\mathrm{m}_{2}}\right),\left(\mathrm{m}_{\mathrm{S}}^{*} \text { with } \mathrm{g}_{\mathrm{a}_{1}}, \mathrm{~g}_{\mathrm{a}_{2}}\right),\left(\mathrm{g}_{\mathrm{a}_{1}} \text { with } \mathrm{g}_{\mathrm{a}_{1}}, \mathrm{~g}_{\mathrm{a}_{2}}\right),\left(\mathrm{g}_{\mathrm{a}_{2}}, \mathrm{~g}_{\mathrm{a}_{2}}\right) \\
& 10.667 \text { to }\left(\mathrm{m}_{\mathrm{S}}^{*}, \mathrm{~m}_{\mathrm{S}}^{*}\right) \\
& -5.333 \text { to }\left(\mathrm{m}_{\mathrm{S}}^{*} \text { with } \mathrm{g}_{\mathrm{m}_{1}}, \mathrm{~g}_{\mathrm{m}_{2}}\right) \\
& -.333 \text { to }\left(\mathrm{g}_{\mathrm{a}_{1}} \text { with } \mathrm{g}_{\mathrm{m}_{1}}, \mathrm{~g}_{\mathrm{m}_{2}}\right),\left(\mathrm{g}_{\mathrm{m}_{1}} \text { with } \mathrm{g}_{\mathrm{a}_{2}}\right),\left(\mathrm{g}_{\mathrm{a}_{2}} \text { with } \mathrm{g}_{\mathrm{m}_{2}}\right) .
\end{aligned}
$$

For non-parent, $\mathrm{C}_{1}$, with sire, $\mathrm{S}$, and dam, $\mathrm{P}_{2}$; the $\mathrm{D}$ value is 2 , so that $\alpha^{*} \square .167, \lambda^{*} \square .021$, $\gamma^{*}$ 口.049, and $\phi_{0}$. .833 . Contributions to right-hand sides: 83.3 to $\mu, \mathrm{p}_{\mathrm{P}_{2}}, \mathrm{~m}_{\mathrm{P}_{2}}^{*}$ and 41.7 to $\mathrm{a}_{\mathrm{P}_{2}}^{*}$, a .

Contributions to coefficient matrix:

$$
\begin{aligned}
& .833 \text { to }\left(\mu \text { with } \mu, \mathrm{p}_{\mathrm{P}_{2}}, \mathrm{~m}_{\mathrm{P}_{2}}^{*}\right),\left(\mathrm{p}_{\mathrm{P}_{2}} \text { with } \mathrm{p}_{\mathrm{P}_{2}}, \mathrm{~m}_{\mathrm{P}_{2}}^{*}\right),\left(\mathrm{m}_{\mathrm{P}_{2}}^{*}, \mathrm{~m}_{\mathrm{P}_{2}}^{*}\right) \\
& .417 \text { to }\left(\mu \text { with } \mathrm{a}_{\mathrm{P}_{2}}^{*}, \mathrm{a}_{\mathrm{S}}^{*}\right),\left(\mathrm{p}_{\mathrm{P}_{2}} \text { with } \mathrm{a}_{\mathrm{P}_{2}}^{*}, \mathrm{a}_{\mathrm{S}}^{*}\right),\left(\mathrm{a}_{\mathrm{P}_{2}}^{*}, \mathrm{~m}_{\mathrm{P}_{2}}^{*}\right),\left(\mathrm{m}_{\mathrm{P}_{2}}^{*}, \mathrm{a}_{\mathrm{S}}^{*}\right) \\
& .208 \text { to }\left(\mathrm{a}_{\mathrm{P}_{2}}^{*} \text { with } \mathrm{a}_{\mathrm{P}_{2}}^{*}, \mathrm{a}_{\mathrm{S}}^{*}\right),\left(\mathrm{a}_{\mathrm{S}}^{*}, \mathrm{a}_{\mathrm{S}}^{*}\right) \text {. }
\end{aligned}
$$

Contributions for $C_{2}$ are the same as those for $C_{1}$ with $C_{2}$ substituted for $C_{1}$ and $B$ substituted for $P_{2}$. For non-parent, $C_{3}$, with sire in group 1 and dam, $B$; the $D$ value is $4 / 3$ so that $\alpha^{*} \square .231, \lambda^{*}=.029, \gamma^{*} \square .074$, and $\phi_{0}$ 口.769. Contributions to right-hand sides: 92.3 to $\mu, \mathrm{p}_{\mathrm{B}}, \mathrm{m}_{\mathrm{B}}^{*}$ and 46.2 to $\mathrm{a}_{\mathrm{B}}^{*}, \mathrm{~g}_{\mathrm{a} l}$.

Contributions to coefficient matrix:

$$
\begin{aligned}
& .769 \text { to }\left(\mu \text { with } \mu, \mathrm{p}_{\mathrm{B}}, \mathrm{m}_{\mathrm{B}}^{*}\right),\left(\mathrm{p}_{\mathrm{B}} \text { with } \mathrm{p}_{\mathrm{B}}, \mathrm{m}_{\mathrm{B}}^{*}\right),\left(\mathrm{m}_{\mathrm{B}}^{*}, \mathrm{~m}_{\mathrm{B}}^{*}\right) \\
& .385 \text { to }\left(\mu \text { with } \mathrm{a}_{\mathrm{B}}^{*}, \mathrm{~g}_{\mathrm{a}}\right),\left(\mathrm{p}_{\mathrm{B}} \text { with } \mathrm{a}_{\mathrm{B}}^{*}, \mathrm{~g}_{\mathrm{a}}\right),\left(\mathrm{a}_{\mathrm{B}}^{*} \text { with } \mathrm{m}_{\mathrm{B}}^{*}\right),\left(\mathrm{m}_{\mathrm{B}}^{*} \text { with } \mathrm{g}_{\mathrm{a} 1}\right) \\
& .192 \text { to }\left(\mathrm{a}_{\mathrm{B}}^{*} \text { with } \mathrm{a}_{\mathrm{B}}^{*}, \mathrm{~g}_{\mathrm{a}}\right),\left(\mathrm{g}_{\mathrm{a} 1}, \mathrm{~g}_{\mathrm{a}}\right) .
\end{aligned}
$$

The coefficient matrix after processing $\mathrm{B}, \mathrm{P}_{1}, \mathrm{P}_{2}, \mathrm{~S}, \mathrm{C}_{1}, \mathrm{C}_{2}$, and $\mathrm{C}_{3}$ is:

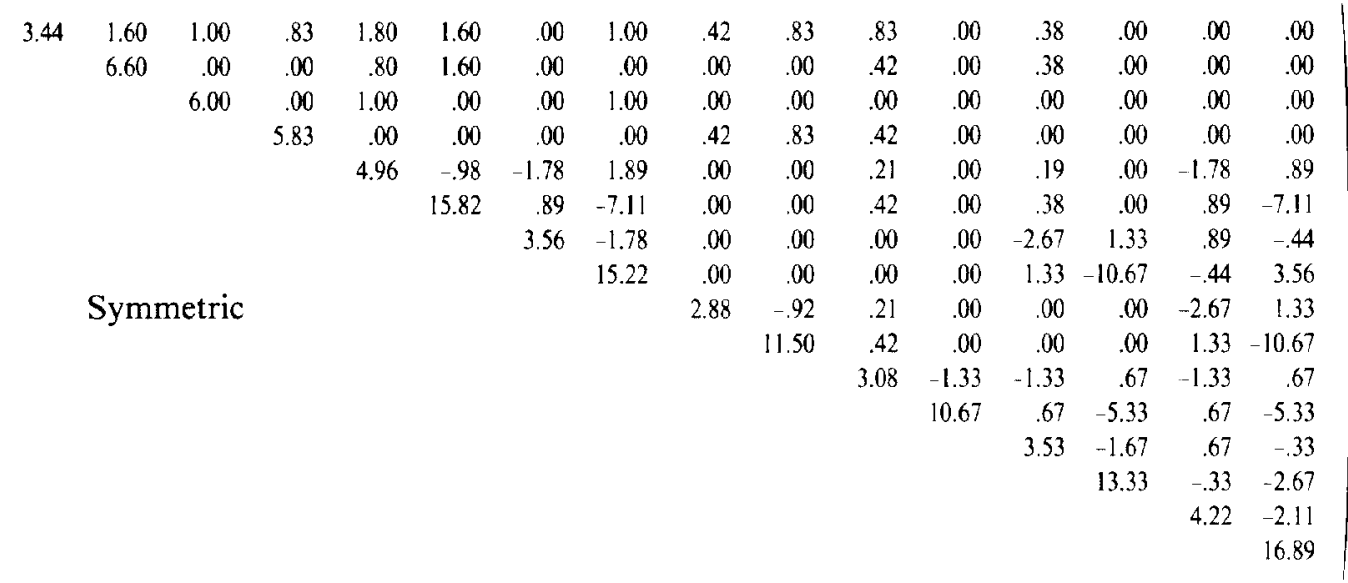


The accumulated right-hand sides are in the third column of Table 5 and the solutions using the same two Lagrange multiplier constraints as for the full set of equations are in the last column of Table 5. The solutions for the parent animals must be, and are, the same as for the full set of equations. If the non-parent block of the full set of equations had been absorbed as a block, the result naturally would be the same.

Back solutions can be obtained from the solutions for parent breeding values, nongenetic maternal effects and fixed effects.

For $\mathrm{C}_{1}$ with $\mathrm{D} \alpha / 2=2 . \overline{6}, \mathrm{D} \lambda / 2$ a $-1 . \overline{3}, \mathrm{D} \gamma / 2=10 . \overline{6}$ :

$\left(\begin{array}{l}\mathrm{a}_{\mathrm{c}_{1}}^{*} \\ \mathrm{~m}_{\mathrm{c}_{1}}^{*}\end{array}\right)=\left(\begin{array}{cc}.1667 & .0208 \\ .0208 & .0495\end{array}\right)\left(\begin{array}{c}100-115.3343-.2432+13.1459-2.6667(.4963+7.2948)+1.3333(.0608+13.1459) \\ 1.3333(7.7811)-10.6667(13.2067)\end{array}\right)$

so that $a_{C_{1}}^{*}=-3.64$ and $m_{C_{1}}^{*}=-6.58$, the same as for the full model except for differences caused by rounding in the example to four decimal places.

\section{Implications}

The rules described here for absorbing non-parent equations will allow animal model evaluations that include maternal effects and genetic groups for both direct and maternal effects to be done essentially as easily as reduced animal model evaluations are now done that do not consider genetic group effects. Because the genetic group effects attempt to account for selection on ancestors that do not have records, the evaluations with group effects should be more accurate than evaluations not considering such selection effects. The advantages of the reduced animal model are retained. The number of equations is reduced by twice the number of non-parents (which often make up a large part of a data set). The memory requirements for efficient computing are reduced because the non-parent solutions are not needed in the basic analysis. Non-parent solutions are easily obtained from a single pass of the non-parent records after solutions for the reduced equations have reached a satisfactory degree of convergence.

\section{Literature Cited}

Benyshek, L. L.., M. H. Johnson, D. E. Little, J. K. Bertrand and L. A. Kriese. 1988. Application of an animal model in the United States beef cattle industry. In: Proc. Animal Model Workshop. J. Dairy Sci. 71(Suppl. 2):35.

Henderson, C. R. 1976. A simple method for computing the inverse of a numerator relationship matrix used in prediction of breeding values. Biometrics 32:69.

Henderson, C. R. 1977. Best linear unbiased prediction of breeding values not in the model for records. $\mathrm{J}$. Dairy Sci. 60:783.

Henderon, C. R. 1985. Equivalent linear models to reduce computations. J. Dairy Sci. 68:2267.

Quaas, R. L. 1976. Computing the diagonal elements and inverse of a large numerator relationship matrix. Biometrics 32:949.

Quaas, R. L. 1988. Additive genetic model with groups and relationships. J. Dairy Sci. $71: 1338$.

Quaas, R. L. and E. J. Pollak. 1980. Mixed model methodology for farm and ranch beef cattle testing programs. J. Anim. Sci. 51:1277.

Quaas, R. L. and E. J. Pollak. 1981. Modified equations for sire models with groups. J. Dairy Sci. 64:1868.

Robinson, G. K. 1986. Group effects and computing strategies for models for estimating breeding values. J. Dairy Sci. 69:3106.
Robinson, J. A. B. and J. P. Chesnais. 1988. Application of the animal model on a national basis to the evaluation of Canadian livestock. Inc: Proc. Animal Model Workshop. J. Dairy Sci. 71 (Suppl.2):70.

Schaeffer, L. R. and B. W. Kennedy. 1986a. Computing strategies for solving mixed model equations. J. Dairy Sci. 69:575.

Schaeffer, L. R. and B. W. Kennedy. 1986b. Computing solutions to mixed model equations. In: Proc. 3rd World Congr. Genet. Appl. Livest. Prod. Lincoln, NE. p. 392.

Thompson, R. 1979. Sire evaluation. Biometrics 35:339.

Van Vleck, L. D. 1990. Breeding value prediction with maternal genetic groups. J. Anim. Sci. 68:3998.

Van Vleck, L. D. and D. J. Dwyer. 1985. Comparison of iterative procedures for solving equations for sire evaluation. J. Dairy Sci. 68:1006.

Westell, R. A. 1984. Simultaneous evaluation of sires and cows for a large population. Ph.D. Dissertation. Cornell Univ., Ithaca, NY.

Westell, R. A., R. L. Quaas and L. D. Van Vleck. 1984. Genetic groups in an animal model. J. Anim. Sci. 59(Suppl.1): 175 (Abstr.).

Westell, R. A.. R. L. Quaas and L. D. Van Vleck. 1988 Genetic groups in an animal model. J. Dairy Sci 71:1310.

Wiggans, G. R., I. Misztal and L. D. Van Vleck. 1988a 
Animal model evaluation of Ayrshire milk yield with all lactations, herd-sire interaction, and groups based on unknown parents. J. Dairy Sci. 71:1319.

Wiggans, G. R., I. Misztal and L. D. Van Vleck. 1988 b.
Implementation of an animal model for genetic evaluation of dairy cattle in the United States. In: Proc. Animal Model Workshop. J. Dairy Sci. 71(Suppl.2):54. 